\title{
Antimicrobial and Hemolytic Activity of Seed Protein Extracts from Selected Medicinal Plants against Tooth Decaying Microorganisms
}

\author{
Megha S Parekh ${ }^{1}$ and Kalpesh B Ishnava ${ }^{1^{*}}$ \\ *Ashok and Rita Patel Institute of Integrated Study and Research in Biotechnology and Allied Sciences \\ (ARIBAS), Sardar Patel University, New Vallabh Vidyanagar-388121, Gujarat, India
}

*Corresponding Author: Kalpesh B Ishnava, Ashok and Rita Patel Institute of Integrated Study and Research in Biotechnology and Allied Sciences (ARIBAS), Sardar Patel University, New Vallabh Vidvanagar-388121, Guiarat, India. Email: ishnavakb203@vahoo.com

\begin{abstract}
All oral diseases, the incidence of those that have a microbial etiology is greatest in all parts of the world. In the present study, the antimicrobial sensitivity assay of plant seed protein extracts against tooth decaying organisms was carried out. 2 out of 10 plant seed protein extracts show their activity against 4 out of total 6 selected oral infection causing bacteria. Inhibition zones against Lactobacillus acidophilus of Acacia nilotica seed protein extract is $16 \mathrm{~mm}$ and Lactobacillus acidophilus and Staphylococcus aureus; the inhibition zone is $4 \mathrm{~mm}$ against Cassia occidentalis. MIC value for Lactobacillus acidophilus and Staphylococcus aureus against Acacia nilotica and Cassia occidentalis seed protein extract is $0.0463 \mu \mathrm{g} / \mathrm{ml}$ and $0.115 \mu \mathrm{g} / \mathrm{ml}$ respectively. The protein content of Acacia nilotica and Cassia occidentalis seed protein extract is $3.801 \mathrm{mg} / \mathrm{ml}$ and $3.842 \mathrm{mg} / \mathrm{ml}$ respectively. Hemolytic activity of Acacia nilotica seed protein has $\mathrm{HC}_{50}$ value of $1.58 \mathrm{mg}$. Kinetic studies of Lactobacillus acidophilus and Staphylococcus aureus the organisms clearly indicate the kinetic of inhibition against both the organisms with respect to time. Treatment with proteinase $K$ of the Acacia nilotica seed protein results in absence of the inhibition zone which clearly indicates the activity is only due to protein. Acacia nilotica seed protein extract maximum protein band present in $40 \mu \mathrm{l}$ sample and 11 protein band are present. Hemolytic activities of the Acacia nilotica plant seed protein gives $\mathrm{HC}_{50}$ value at a very high range than that of the MIC values against both of the organisms and thus flourish its application as successful pharmaceutical drug in practice.
\end{abstract}

Keywords: Medicinal Plants, Seed Protein, Antimicrobial protein, Antimicrobial activity, Hemolytic activity, Proteinase $K$

\section{INTRODUCTION}

Tooth rotting issue watched all over the world. The verbal depression is exceptionally complex and heterogeneous microbial environment. All verbal infections, the rate of those that have a microbial etiology is most prominent in all parts of the world. There are basically numerous diverse sorts of microbes included in tooth rotting prepare. Such as mutans group of streptococci, S. salvarious, S. mitis, S. milleri, S. oralis, S. sanguis, Lactobacillus casei, Actinomyces viscosus etc,. [1, 2]. The mineral substance of teeth is touchy to increments in causticity from the generation of lactic corrosive. Particularly, a tooth is in a steady state of back-and-forth demineralization and remineralization between the tooth and encompassing spit. When the $\mathrm{pH}$ at the surface of the tooth drops underneath 5.5, demineralization continues speedier than remineralization. This comes about within the resulting rot. Tooth rot is caused by particular sorts of acid-producing bacteria that cause harm within the nearness of fermentable carbohydrates such as sucrose, fructose, and glucose [3] Over 750 species of bacteria inhabit the oral cavity and a number of these are implicated in oral diseases [4]. The improvement of dental caries includes acidogenic and aciduric Gram-positive microbes, fundamentally the mutans streptococci, lactobacilli and actinomycetes, which metabolize sucrose to natural acids that break down the calcium phosphate in teeth, causing decalcification and inevitable rot. Dental caries is in this way a supragingival condition [2]. In spite of a few operators being commercially accessible, these chemicals can modify verbal microbiota and have undesirable sideeffects such as heaving, the runs and tooth recoloring [5]. For example, bacterial resistance to most of the antibiotics commonly used to treat oral infections has been documented [6]. Hence, the search for 
alternative products continues and natural phytochemicals isolated from plants used in traditional medicine are considered as good alternatives to synthetic chemicals [7].

The utilize of conventional pharmaceutical and restorative plants in most creating nations, as a standardizing premise for the support of great wellbeing, has been broadly watched UNESCO (1996) [8]. In rustic zones of the creating nations, they proceed to be utilized as the essential source of pharmaceutical [9]. Around $80 \%$ of people shapes created nations utilize conventional medication which has compounds inferred from therapeutic plants $[10,11]$. In later a long time, antimicrobial properties of therapeutic plants are being progressively detailed from distinctive parts of the world $[12,13]$.

To keep out potential trespassers, plants deliver a wide extend of particular antibacterial compounds either in a constitutive or an inducible way [14]. Among these compounds a few moo atomic weight proteins or peptides with antibacterial or antifungal action have been confined in later a long time from different plants and are accepted to be included in a resistance component against phytopathogenic organisms by hindering microorganisms development. Additionally, the amalgamation of numerous assumed defense related proteins are initiated when plants are gone up against with pathogens [15]. Plants have different little antimicrobial peptides which are cysteine-rich and profoundly fundamental [16]. Antimicrobial proteins (AMPs), as vital antibacterial and antifungal compounds, have pulled in consideration of a huge number of examiners. AMPs are to a great extent dispersed among living beings counting plants, creatures, parasites and a few single-celled microorganisms [17]. To date, distinctive proteins with antibacterialor antifungal action have been detailed [18]. Normal peptides/proteins or their analogs have been found with shifting exercises against pathogens, extreme, to date, as it were a number of have entered clinical trials. Undoubtedly, many more stay to be found, as a result analogs can be more strong than their guardians, future inquire about will certainly discover novel peptides with potential pharmaceutical utility [19].

The objective of this consider was at that point to examine the inhibitory impact of the seed protein extricates from a few plants on cariogenic life forms beneath in vitro condition conjointly counting the impact of the inhibitory extricates on human ruddy blood cells. The reason for this is often to supply a scientific legitimacy for their utilize for controlling verbal living beings with security to people. There's a less data with respect to bioactivity of seed protein extricates of therapeutic plants against cariogenic microorganisms. These data will may be valuable to rummage around for unused costeffective drugs of common root in future. The rummage around for modern antibacterial compounds which have diverse instruments of activity from those which are in current utilize may rise an elective way for fathoming the same issue.

\section{Material AND MethodS}

\subsection{Collection and Processing of Plant Samples}

The different plant species seeds were selected and collected from different part of Gujarat and surroundings of Vallabh Vidyanagar (Table-1). Healthy and disease free plant seeds were used to test the anticariogenic activity. The plant specimens were identified by Dr. Kalpesh Ishnava (Plant Taxonomist) at Ashok and Rita Patel Institute of Integrated Study \& Research in Biotechnology and Allied Sciences (ARIBAS), New Vallabh Vidyanagar, Gujarat, India.

Table1. Details of selected plant seeds

\begin{tabular}{|l|l|l|l|c|}
\hline Sr. No & \multicolumn{1}{|c|}{ Botanical Name } & \multicolumn{1}{c|}{ Family } & \multicolumn{1}{c|}{ Local Name } & Collection Site \\
\hline A. & Withania somnifera (L.) Dunal & Solanaceae & Ashvagandha & Anand \\
\hline B. & Solanum incanum L. & Solanaceae & Ubhiringni & Napa \\
\hline C. & Solanum surattense Burn. & Solanaceae & Bhoyringani & Mogari \\
\hline D. & Achyranthea aspera L. & Amaranthaceae & Anghedi & Gana \\
\hline E. & Dendrocalamus strictus Nees & Poaceae & Vans & V.V.Nagar \\
\hline F. & Nyctanthus arbortristis L. & Oleaceae & Parijatak & V.V.Nagar \\
\hline G. & Acacia nilotica (L.) Del. & Mimosaceae & Baval & Karmsad \\
\hline H. & Cassia occidentalis L. & Caesalpiniaceae & Kasundri & Boravi \\
\hline I. & Cassia tora L. & Caesalpiniaceae & Kuvandio & Jor \\
\hline J. & Azadirachta indica A.juss. & Meliaceae & Limdo & V.V.Nagar \\
\hline
\end{tabular}




\subsection{Extraction of Antimicrobial Proteins from Plant Seed Samples}

Antimicrobial proteins were extracted from the plant seeds using $10 \mathrm{mM}$ of sodium phosphate buffer $(\mathrm{pH}$ - 7.0) [20]. All the seeds of respective plants were thoroughly washed with running tap water, blotted and dried under sunlight. After drying the plant seeds were transferred immediately to the laboratory and used for experiments. The buffer was prepared and seeds of all the plants were grinded in pre-cooled mortar and pestle with extraction buffer in 1:3 ratios i.e. $1 \mathrm{gm}$ of seed in $3 \mathrm{ml}$ of buffer; and the extract was harvested in $50 \mathrm{ml}$ centrifuge tube. This extract was centrifuged at $10,000 \mathrm{rpm}$ at $4^{\circ} \mathrm{C}$ for $20 \mathrm{~min}$. The crude extract isolated (supernatant) was saturated with $80 \%$ ammonium sulphate. Now, this saturated crude extract was again centrifuged at $13,000 \mathrm{rpm}$ at $4^{\circ} \mathrm{C}$ for $30 \mathrm{~min}$ to pellet down the precipitated proteins. Pellet further resuspended in the buffer and subjected for purification of protein concentrate using dialysis bag.

\subsection{Purification of the Protein using Dialysis Bag}

Dialysis bag was cut according to the volume of the proteins to be purified (capacity: $1 \mathrm{~cm}$ of lenth $2 \mathrm{ml}$ of extract) and firstly dip into the buffer for $10 \mathrm{~min}$. Then one of its ends was twisted and tied with a thread and checked for any leakage. After that, protein solution was poured into the dialysis bag with one closed end and the other open end was also tightly packed with thread as shown above. Now, this 'toffee wrapper' like packed protein in the dialysis bag was put into the beaker containing $1 \mathrm{~L}$ of the extraction buffer and whole assembly was put on the magnetic stirrer for at least $3 \mathrm{hrs}$ and then the buffer was changed. Repeat this for three times. Finally all ammonium salts were remove out in the buffer, outside of the dialysis bag, and only protein suspended in the buffer remains inside the bag which can be directly subjected for further studies and antimicrobial assay.

\subsection{Bioassay for Antimicrobial Activity}

\subsubsection{Agar Well Diffusion Method}

In the present study, to test antibacterial activity, 10 different plant seed extracts were used. The antibacterial activity was studied by agar well diffusion method [21]. The bacterial cultures were revived by using MTCC (Microbial Type Culture Collection (MTCC) bank, Chandigarh) specified selective growth medium and preserved as glycerol stocks. The bacteria (Lactobacillus acidophilus (LA)-MTCC No.*447; Lactobacillus casei (LC)-MTCC No.1423; Staphylococcus aureus (SA)-MTCC No.96; Streptococcus mutans (SM)-MTCC No.890; Candida albicans (CA)-MTCC No.183; Streptococcus pyogenes (SP)-MTCC No.442) responsible for dental caries used for the study. From the stock, $100 \mathrm{mg}$ of each plant extract were suspended in one millilitre of Dimethyl sulfoxide (DMSO). The zone of inhibition (excluding well diameter) was measured as a property of antibacterial activity. Antibiotics; ampicillin, amoxyilin and tetracycline was used as standard at a concentration of $100 \mu \mathrm{g} / \mathrm{mL}$. Bioassay was performed in duplicate and repeated twice.

\subsection{MIC of the Protein Extracts}

Minimum inhibitory concentration (MIC) was evaluated by the two fold serial broth dilution method [22]. Negative control used as DMSO and positive control use as bacterial culture of Staphylococcus aureus and Lactobacillus acidophilus. Each assay was repeated thrice by using DMSO and selective medium as control.

\subsection{Estimation of Protein Concentration of Seed Extracts}

Estimation of protein concentration of seed extracts find out by the BSA standard estimation method [23]. This method is useful only with comparatively pure solutions. Most proteins exhibit a distinct absorption peak in the UV range at $280 \mathrm{~nm}$ and this is due to the presence of tyrosine and tryptophan. Pipette out $0.2,0.4,0.6,0.8$ and $1.0 \mathrm{ml}$ of a standard protein solution into a series of tubes. Make the volume in each tube with water to $2 \mathrm{ml}$ and mix. Measure the absorbance of standards and sample at 280 $\mathrm{nm}$ against the blank in a spectrophotometer.

\subsection{Kinetic Study of Crude Seed Protein Extracts}

Kinetic study of crude seed protein extracts method followed reported by Kareem et al., (2008) [24]. An overnight broth culture of Staphylococcus aureus and Lactobacillus acidophilus were taken for the study and different assemblies were prepared for the kinetic study. Staphylococcus aureus assembly 
(Culture flask - $45 \mathrm{ml}$ of fresh nutrient broth $+5 \mathrm{ml}$ of Staphylococcus aureus culture; Test flask - 45 $\mathrm{ml}$ of fresh nutrient broth $+5 \mathrm{ml}$ of Staphylococcus aureus culture $+3 \mathrm{ml}$ of the crude seed protein extract of Cassia occidentalis) and Lactobacillus acidophilus assembly(Culture flask - $45 \mathrm{ml}$ of fresh nutrient broth $+5 \mathrm{ml}$ of Lactobacillus acidophilus culture; Test flask - $45 \mathrm{ml}$ of fresh nutrient broth + $5 \mathrm{ml}$ of Lactobacillus acidophilus culture $+3 \mathrm{ml}$ of the crude seed protein extract Acacia nilotica). The all 5 culture flasks were subjected to a shaker incubator at $37^{\circ} \mathrm{C}$. The optical density $(427 \mathrm{~nm})$ was determined at every 60 minutes intervals for six hours using spectrophotometer to obtain both the curves of normal growth in culture flask and inhibitory effect in the test flask for Staphylococcus aureus and Lactobacillus acidophilus.

\subsection{Hemolytic Activity of Acacia nilotica Crude Seed Protein}

Hemolytic activity was evaluated as described previously by Andra et al., (2008) with a slight modification [25]. Hemolytic activity was expressed as a percentage hemolysis, which was calculated using the following equation:

$$
\% \text { Hemolysis }=\frac{\text { Asample }- \text { A buffer }}{\text { Amax }- \text { buffer }} \times 100
$$

Where 'Asample' is A540 of red blood cells with protein extract in stock human erythrocyte suspension, 'Abuffer' is A540 of red blood cells in PBS, and 'Amax' is A540 of red blood cells with $1 \%(\mathrm{v} / \mathrm{v})$ Triton X-100in PBS. No haemolysis (0\%) and full hemolysis $(100 \%)$ were observed in the presence of PBS and 1\% (v/v) Triton X-100, respectively.

\subsection{Treatment of Proteinase K on Acacia nilotica Crude Seed Protein Extract}

In order to figure out whether antibacterial activity is the cause of proteins in the crude extract, the crude extract was treated with proteolytic enzyme; Proteinase K. Proteinase K was added into $200 \mu \mathrm{L}$ of crude extract $(5.84 \mathrm{mg} / \mathrm{mL}$ protein) in which the protein amount ratio of protein substrate and proteolytic enzymes equaled to $1: 8$. The treatment reaction was performed at $37^{\circ} \mathrm{C}$ for $20 \mathrm{~h}$ [26]. After treatment, the supernatant was obtained by centrifugation at $10,000 \mathrm{rpm}$ for $5 \mathrm{~min}$ and used for antibacterial activity assay.

\subsection{Acacia nilotica Crude Protein Profiling by SDS-PAGE}

Prepare polyacrylamide gel (12\%) according to standard protocol followed by Hiral et al., (2014) [27]. Load samples and run gel at $25 \mathrm{~mA}(2$ gels run at $50 \mathrm{~mA})$ in $1 \mathrm{x}$ SDS running buffer. At this point, the gel can either be transferred to a membrane. Place gel in a plastic container. Cover with isopropanol fixing solution and shake at room temperature. For $0.75 \mathrm{~mm}$-thick gels shake 10 to 15 $\mathrm{min}$; for $1.5 \mathrm{~mm}$ thick gels, shake 30 to $60 \mathrm{~min}$. Pour off fixing solution. Cover with coomassie blue staining solution and shake at room temperature for $2 \mathrm{hr}$. Pour off staining solution. Wash gel with $10 \%$ acetic acid to detain, shaking at temperature on.

\section{RESUlT AND DISCUSSION}

In the present study, the antimicrobial sensitivity assay of plant seed protein extracts against tooth decaying organisms was carried out. The proteins from seeds of 10 different plants were extracted and then used for antimicrobial assay. The result of sensitivity of crude plant seed proteins extracts against the tooth decaying organisms (CA, LA, LC, SA,SMU and SP) were assessed by visualizing the presence or absence of inhibition zone and measuring diameter of the zone of inhibition.

\subsection{Antimicrobial Activity}

\subsubsection{Candida Albicans}

The crude seed protein extract of Acacia nilotica has showed its activity against this organism as show in the Figure 1. Out of 10 plant seed protein extracts; only one plant seed protein extracts has shown the activity and rest of the plant seed protein extracts having no activity against this cariogenic microorganism (Figure 1). Antibiotic amphotericin, tetracycline and amoxicillin demonstrated 8,8 and $6 \mathrm{~mm}$ zones of inhibitions respectively (Figure-1). Compare to this plant seed extract has activity of $4 \mathrm{~mm}$ zone of inhibitions. The protein extract are not good activity compare to the entire three antibiotics against this cariogenic microorganism. 


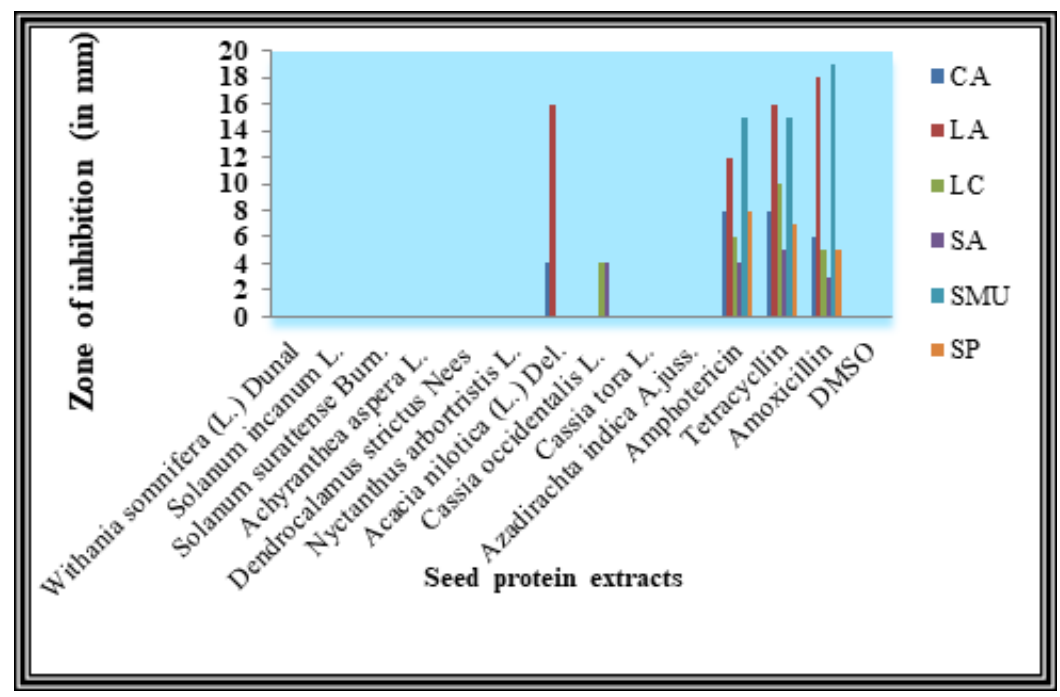

Figure1. Antibacterial activity of seed protein extracts against cariogenic microorganisms

\subsubsection{Lactobacillus Acidophilus}

Out of 10 plant seed protein extracts; only one plant seed protein extracts has shown the activity and rest of the plant seed protein extracts having no activity against this cariogenic microorganism (Figure 1). Antibiotic activity of amphotericin, tetracycline and amoxicillin are 12, 16 and 18 respectively (Figure 1). The crude seed protein extract of Acacia nilotica $(16 \mathrm{~mm})$ has show their activities against this organism good activity compare to the entire three antibiotics against this cariogenic microorganism.

Solomon-Wisdom and Shittu (2010) reported the in vitro antimicrobial and phytochemical activities of the crude ethanolic leaf extract of Acacia nilotica on Campylobacter coli isolated from goats in Gwagwalada Abattoir [28]. Minimum inhibitory concentration was $70 \mathrm{mg} / \mathrm{ml}$ of the extract related to standardized bacteria colony of $3 \times 10^{8}$ organisms per mL. The highest zone of inhibition was observed with the $70 \mathrm{mg} / \mathrm{ml}$ concentration. The basis of this plant extract in the traditional treatment of diarrhea in human is highlighted. The zones of inhibitions observed were of the $8 \mathrm{~mm}$ and $15 \mathrm{~mm}$ respectively. The zone of inhibitions for this organism is $6 \mathrm{~mm}$ comparative quite high against of those organisms. Thus, primary metabolites give more activity than that of secondary metabolites in the case of anticariogenic activity. The compare to seed protein extract better than leaf ethanolic extract. The phytochemical screening of the A nilotica leaf extracts has shown that the leaf contains saponins, saponin glycosides, volatile oil, hydrolysable tannin, triterpenoid, tannins, flavonoids, phenol, alkaloids which are very important constituent when looking for pharmacologically active phytochemicals in the plant. This study show the secondary metabolites compare to primary metabolites like protein also good activity against antibacterial activity.

\subsubsection{Lactobacillus Casei}

The crude seed protein extract of Cassia occidentalis has showed its activity against this organism as show in the Figure1. Out of 10 plant seed protein extracts; only one plant seed protein extracts has shown the activity and rest of the plant seed protein extracts having no activity against this cariogenic microorganism (Figure-1). Antibiotic amphotericin, tetracycline and amoxicillin demonstrated 6,10 and $5 \mathrm{~mm}$ zones of inhibitions respectively; compare to this plant seed extract has activity of $4 \mathrm{~mm}$ zone of inhibitions (Figure-1). The protein extract is not good activity compare to the entire three antibiotics against this cariogenic microorganism.

\subsubsection{Staphylococcus Aureus}

The crude seed protein extract of Cassia occidentalis has showed its activity against this organism as show in the Figure 1. Out of 10 plant seed protein extracts; only one plant seed protein extracts has shown the activity and rest of the plant seed protein extracts having no activity against this cariogenic microorganism (Figure-1). Antibiotic amphotericin, tetracycline and amoxicillin demonstrated 4, 5 and $3 \mathrm{~mm}$ zones of inhibitions respectively; compare to this plant seed extract has activity of $4 \mathrm{~mm}$ zone of inhibitions (Figure 1). The protein extract is good activity compare to the entire three antibiotics against this cariogenic microorganism. 
Antimicrobial and Hemolytic Activity of Seed Protein Extracts from Selected Medicinal Plants against Tooth Decaying Microorganisms

\subsubsection{Streptococcus Mutans}

All the 10 plant seed protein extracts have shown no activity against this organism. Antibiotic activity of amphotericin, tetracycline and amoxicillin are 15,15 and 19 respectively. ( Figure 1).

\subsubsection{Streptococcus Pyogenes}

All the 10 plant seed protein extracts have shown no activity against this organism. Antibiotic activity of amphotericin, tetracycline and amoxicillin are 8, 7 and 5 respectively (Figure 1).

\subsection{Minimum Inhibitory Concentration (MIC)}

According to two fold serial broth dilution method assay, Acacia nilotica and Cassia occidentalis crude extract showed inhibition towards two of the tested cariogenic bacteria. MIC values of the crude extract toward these two strains were evaluated, with results as shown in Table 2 . In the case of Acacia nilotica seed protein extract; MIC values are $0.0463 \mu \mathrm{g} / \mathrm{ml}$ against Lactobacillus acidophilus and Cassia occidentalis against Staphylococcus aureus MIC values are $0.115 \mu \mathrm{g} / \mathrm{ml}$. Sensitivity towards both the bacteria by Acacia nilotica and Cassia occidentalis seed crude protein extract was Lactobacillus acidophilus > Staphylococcus aureus. The extract of Acacia nilotica seeds was well active on gram positive bacteria. It has been reported that crude protein extracts of cruciferous vegetables had greater inhibitory effects against Gram negative bacteria than Grampositive bacteria [29]. Pankit (2011) reported in crude protein extract of Mimusops elengi seeds have been reported to possess antibacterial activities against $S$. aureus (MIC $364.36 \mathrm{mg} / \mathrm{mL}$ ) [30]. Crude protein extract of Moringa oleifera seeds have been reported to possess antibacterial activities against $S$. aureus (MIC $24.0 \mathrm{mg} / \mathrm{mL}$ ). It is possible that the response molecule for antibacterial activity in Acacia nilotica and Cassia occidentalis crude extract might be protein or peptide. Acacia nilotica and Cassia occidentalis crude extract showed interesting antibacterial activities which could inhibit all tested gram positive. These MIC values are much more than our results which showed that crude extract of Acacia nilotica and Cassia occidentalis seeds are more potent for bacterial inhibition [31]. It is widely use both medicinal plants for solve the tooth problem disease traditionally. A significant MIC value against the tested bacteria indicates this extract has a high potential for widespread applications.

Table2. MIC of selected plant seed extract against cariogenic bacteria.

\begin{tabular}{|l|l|l|l|l|l|l|l|}
\hline \multirow{2}{*}{ Sr. No } & \multirow{2}{*}{ PLANT NAME } & \multicolumn{4}{|l|}{ MICROORGANISMS $(\boldsymbol{\mu g} / \mathbf{m l})$} & SMU & SP \\
\cline { 3 - 8 } & & CA & LA & LC & SA & SMU \\
\hline 1 & Acacia nilotica & - & $\mathbf{0 . 0 4 6 3}$ & - & - & - & - \\
\hline 2 & Cassia occidentalis & - & - & - & 0.115 & - & - \\
\hline
\end{tabular}

\subsection{Protein Concentration}

\subsubsection{Protein Content of Crude Extract from Selected Seeds}

$1 \mathrm{gm}$ of dry seed extracts in $3 \mathrm{ml}$ of $10 \mathrm{mM}$ Sodium phosphate buffer. BSA standard method using find out the concentration for selected seed protein extracts. Obtained protein concentrations as mention the value in table in $\mathrm{mg} / \mathrm{ml}$ (Table 3 ). This concentration was again conformed by Nanodrop; showing same reading for the amount of protein present in the sample. The maximum concentration is present in the seed protein extract of Cassia occidentalis and Acacia nilotica is 3.842 and $3.801 \mathrm{mg} / \mathrm{ml}$ respectively.

Table3. Protein concentration of selected seed protein extracts

\begin{tabular}{|l|l|l|}
\hline Sr. No & BOTANICAL NAME & Concentration $\mathbf{~ m g / m l}$ \\
\hline $\mathbf{1 .}$ & Withania somnifera (L.) Dunal & 3.00 \\
\hline $\mathbf{2 .}$ & Solanum incanum L. & 3.00 \\
\hline $\mathbf{3 .}$ & Solanum surattense Burn. & 3.00 \\
\hline $\mathbf{4 .}$ & Achyranthea aspera L. & 3.714 \\
\hline $\mathbf{5 .}$ & Dendrocalamus strictus Nees & 3.751 \\
\hline $\mathbf{6 .}$ & Nyctanthus arbortristis L. & 3.627 \\
\hline $\mathbf{7 .}$ & Acacia nilotica (L.) Del. & 3.801 \\
\hline $\mathbf{8 .}$ & Cassia occidentalis L. & 3.842 \\
\hline $\mathbf{9 .}$ & Cassia tora L. & 3.777 \\
\hline $\mathbf{1 0 .}$ & Azadirachta indica A.juss. & 3.777 \\
\hline
\end{tabular}

International Journal of Research Studies in Microbiology and Biotechnology (IJRSMB) $\quad$ Page | 43 


\subsection{Kinetic of Antibacterial Acticvity}

The study on the effect of plant seed protein extract of Acacia nilotica and Cassia occidentalis on the growth dynamics of Lactobacillus acidophilus and Staphylococcus aureus respectively was done in compare with the normal growth (Figure-2 \&3). Both of the organisms when exposed to the plant seed extract at doses equivalent to MIC; demonstrates decline in population after 1 hours and $20 \mathrm{~min}$ of exposure. It was observed that the both the seed protein extracts could be said to be bacteriostatic. Kshipra and amla (2011) reported in vivo and in vitro protein profile 33 bands in Acacia nilotica [32]. The protein are present is low molecular weight. It is more effective comparative to protein high molecular weight. Cassia occidentalis plant seed near by the very close family of Acacia nilotica. Cassia occidentalis also present is low molecular weight. The detail study are required both the plants. This data show the after $7 \mathrm{hrs}$ also bacteriostatic of seed protein extract. The both the seed protein extracts against both the organisms are within $1 \mathrm{hrs}$ and $20 \mathrm{mim}$ kill the bacteria. The data from kinetics studies also provide an idea for the vehicle system that should be used to deliver an antibacterial agent to the oral cavity [33]. It was also noted that antimicrobial growth dynamics was both dose and time dependent and this is a more rational basis for determining optimal dosage for antimicrobial treatment regimens [34]. The mechanisms by which microorganisms generally survive and the action of antimicrobial agents are poorly understood and remain debatable [35].

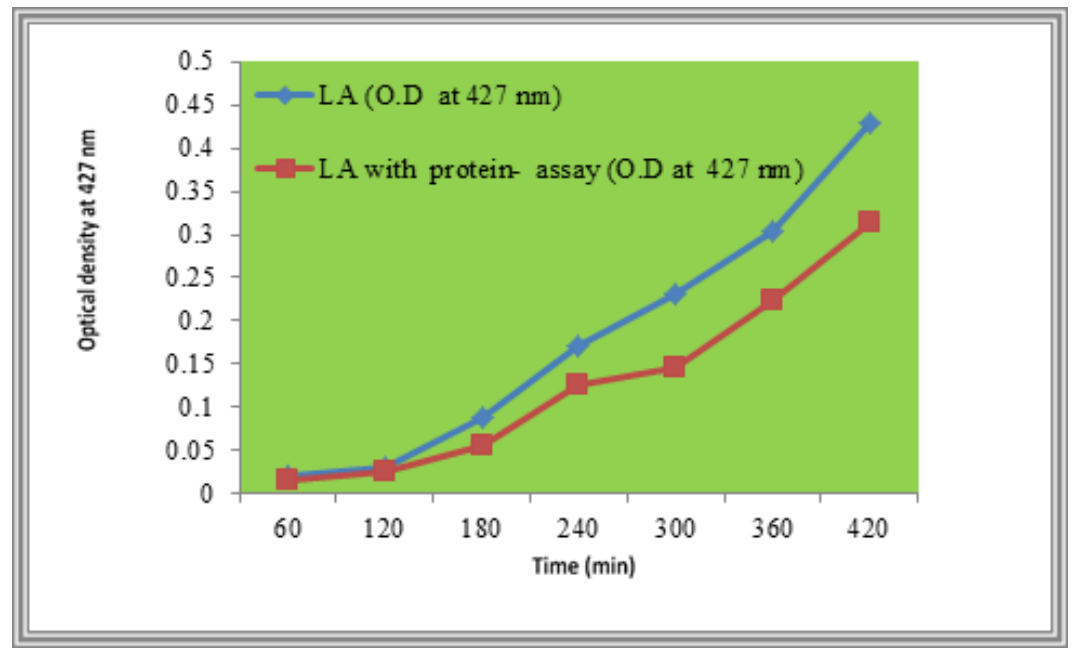

Figure2. Inhibition kinetics of antimicrobial activities of seed protein extract of Acacia nilotica against Lactobacillus acidophilus

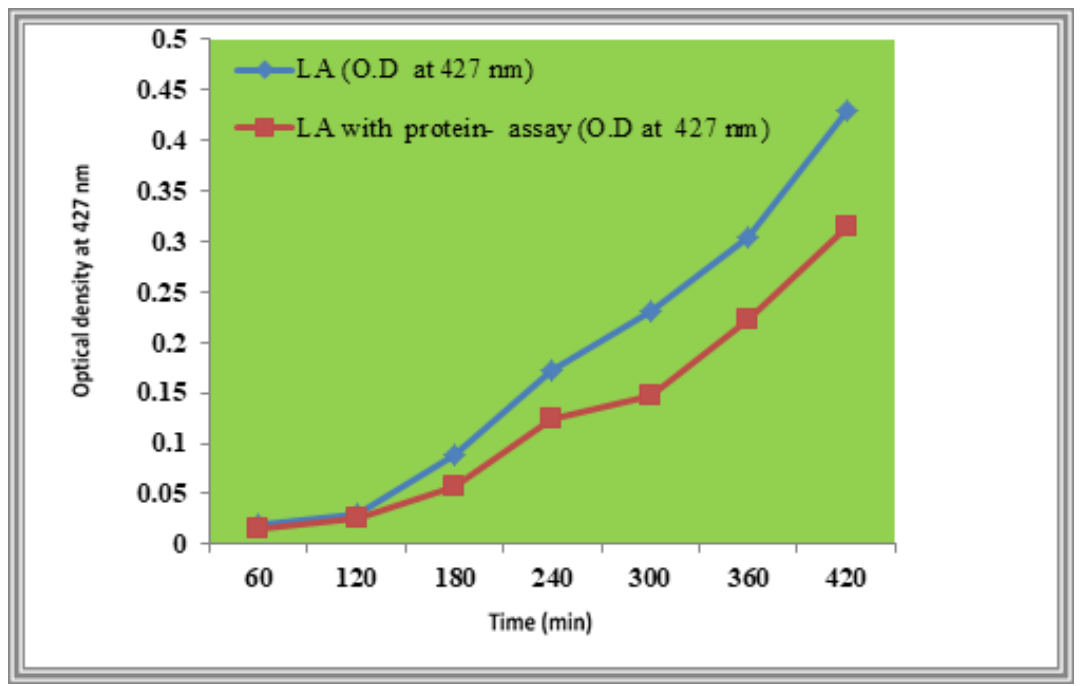

Figure3. Inhibition kinetics of antimicrobial activities of seed protein extract of Cassia occidentalis against Staphylococcus aureus

An agent capable of killing oral bacteria within minutes of exposure can be used in a product like toothpaste or mouthwash since brushing or rinsing usually takes only a few minutes [36]. The extract 
might be formulated in a delivery vehicle such as chewing-gum, gel or vanish that can sustain its release over a period of time. Further studies are required to determine the side effects and the antibacterial activity of the extract when used over a period of time in the oral cavity.

\subsection{Protease Activity}

\subsubsection{Proteinase K Treatment}

The Acacia nilotica crude seed protein extract after treatment with protein hydrolytic enzymes, proteinase $\mathrm{K}$ revealed no further activity of the extract against Lactobacillus acidophilus (Table 4) which conforms the antimicrobial activity was only in the presence of fully structured protein and after its destruction or hydrolysis by enzyme; the activity vanish.

Table4. Inhibition zone of Acacia nilotica crude extract after treatment with proteinase $K$

\begin{tabular}{|c|c|c|}
\hline Samples & Loaded protein $(\boldsymbol{\mu l})$ & Inhibition zone $(\mathbf{m m})$ \\
\cline { 3 - 3 } & & LA \\
\hline Crude extract & 100 & 16 \\
\hline Crude extract + Proteinase K & 100 & 0 \\
\hline
\end{tabular}

\subsubsection{Crude Seed Protein Profiling by SDS-PAGE}

Acacia nilotica crude protein profiling by SDS -PAGE (Figure 4). SDS-PAGE is considered as a reliable method of genetic characterization because electrophoretic patterns of the protein fractions are directly related to the genetic background of the proteins and can be used to certify the genetic make-up [37]. In order to estimate the variability at genetic level, SDS-PAGE banding pattern of the gel using total protein was investigated. Overall out of 11 protein bands, molecular weights $25,50,75$ and $97 \mathrm{KDa}$ shown same protein banding pattern in seed samples but with variation in intensities. The protein sample load 40,30, $20 \mu \mathrm{l}$ in variable amount and separating gel $12 \%$ for study the banding pattern. Kshipra and Amla (2011) reported the in vivo and in vitro protein profiling in Acacia nilotica [32]. Overall out of 33 protein bands, molecular weights 19.5, 28.5 and 42.3 KDa shown same protein banding pattern in callus, in vivo leaves, stem and seed samples but with variation in intensities in Acacia nilotica. Left behind protein banding pattern exhibited a considerable range of variability with regard to their mobilities and intensities. Seed only lacking at the molecular weight 35.6 KDa. These results are also similar but numbers of band are less in our sample of Acacia nilotica seed protein extracts. It may be sample are more load in SDS -PAGE. From this we concluded that the highest numbers of protein bands were observed in $40 \mu 1$ sample load in the gel of Acacia nilotica seed protein extract. This study presents and sheds light on the Acacia nilotica L. proteins which are useful in the kill the tooth decaying organisms.

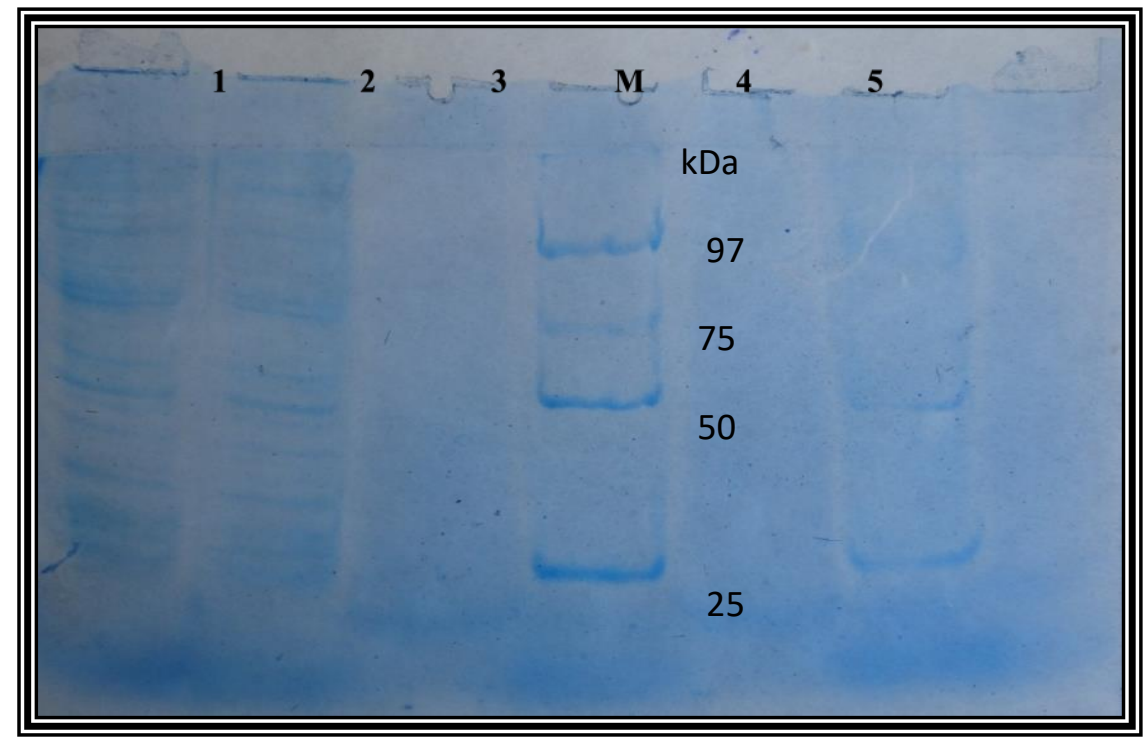

Figure4. Acacia nilotica crude seed protein profiling by SDS-PAGE

$1.40 \mu \mathrm{l}$ sample load $2.30 \mu \mathrm{l}$ sample load3.20 $\mu 1$ sample load M- Medium range protein marker (14-97kDa) 4.10 $\mu 1$ sample load 5. $05 \mu$ l sample load 


\subsection{Hemolytic Activity}

Several antimicrobial peptides have been reported to exhibit cytotoxic activity against eukaryotic cells. Therefore, Acacia nilotica crude extract in which peptides were expected as antibacterial molecules was tested for hemolytic activity against human erythrocytes (Figure 5). It was found that Acacia nilotica crude extract showed hemolytic activity against human erythrocytes in a dosedependent manner with concentration of protein at which 50\% hemolytic compared to Triton X-100 treatment $\left(\mathrm{HC}_{50}\right)$ value equaled to $1.58 \mathrm{mg} / \mathrm{ml}$. No hemolysis $(0 \%)$ and full hemolysis $(100 \%)$ were observed in the presence of PBS and 1\% (v/v) Triton X-100, respectively.

Thus, according to graph $\mathrm{HC}_{50}$ value for the sample is at $1.58 \mathrm{mg}$ compare to Triton $\mathrm{X}-100 . \mathrm{HC}_{50}$ value is about 15 times larger than the MIC value against Lactobacillus acidophilus. The well-known hemolytic peptide mellitin has been reported to cause $50 \%$ hemolysis at $7.5 \mu \mathrm{g} / \mathrm{mL}$ [38]. The $\mathrm{HC}_{50}$ value from Acacia nilotica crude extract is far larger than that of mellitin and accompanies consideration with the MIC values against the tested bacteria. These results imply that the application of this crude extract might be possible for safe use with humans.

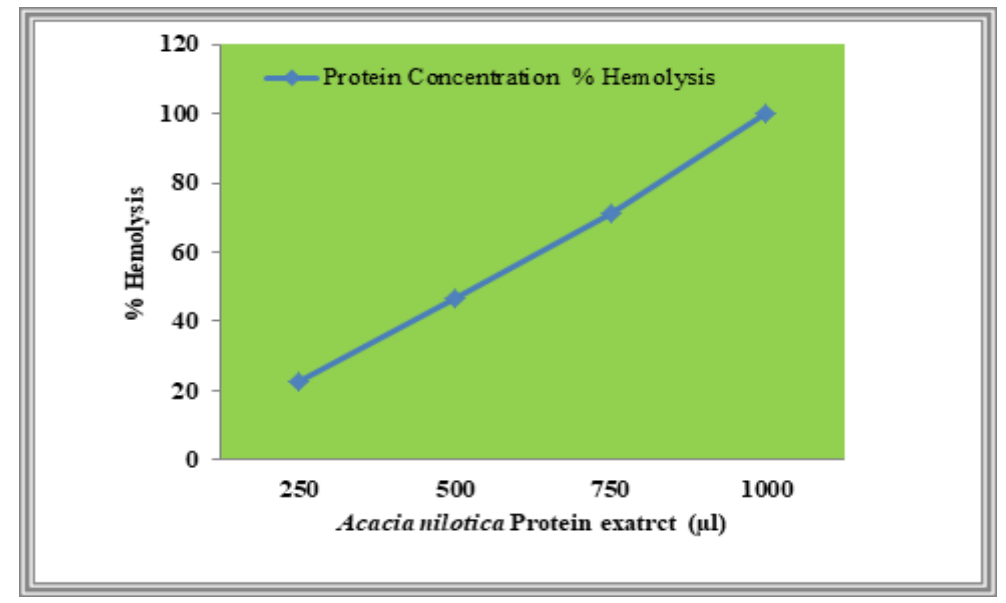

Figure5. Susceptibility of freshly collected erythrocytes to hemolysis (\%) with seed protein extract of Acacia nilotica

\section{CONCLuSiON}

This study concludes that $10 \mathrm{mM}$ of sodium phosphate buffer $(\mathrm{pH} 7.0)$ use for the extraction is proficient for retrieving good amount of the protein from the plant sample and proven as the reliable extraction buffer. More than three times of higher inhibition zones compare to antibiotics for both Lactobacillus acidophilus and Staphylococcus aureus of Acacia nilotica plant seed protein extract clearly show the prominence of the inhibitory protein. Moreover, MIC study indicates that Lactobacillus acidophilus is little more susceptible towards the Acacia nilotica plant seed protein than that of Staphylococcus aureus by showing lower MIC value compare to Staphylococcus aureus. Kinetic study further elucidates the kinetic of inhibition and confirms the inhibitory activity in the presence of the Acacia nilotica and Cassia occidentalis plant seed protein in context to time. Treatment with Proteinase K confirms that the inhibitory activity was only due to the protein present in the sample because after its treatment with proteinase $\mathrm{K}$ sample loses its capability of inhibition against both of the organisms as protein was hydrolyzed by the enzyme. Finally, haemolytic activities of the Acacia nilotica plant seed protein gives $\mathrm{HC}_{50}$ value at a very high range than that of the MIC values against both of the organisms and thus flourish its application as successful pharmaceutical drug in practice. Further work on the present study must be needed. The mode of action for Acacia nilotica plant seed protein extract on both Staphylococcus aureus and Lactobacillus acidophilus could be established using SEM.

\section{ACKNOWLEDGMENTS}

Authors are thankful to Charutar Vidya Mandal (CVM), Vallabh Vidyanagar and Director of Ashok and Rita Patel Institute of Integrated Studies and Research in Biotechnology and Allied Sciences (ARIBAS), New Vallabh Vidyanagar, Gujarat, India for providing necessary support for research and laboratory facility. 


\section{REFERENCES}

[1] Loesche WJ (1996). Microbiology of Dental Decay and Periodontal Disease. In: Baron's Medical Microbiology (Baron S et al., eds.) (4th ed.). University of Texas Medical Branch.

[2] Loesche W (2007). Dental caries and periodontitis: contrasting two infections that have medical implications. Infect Dis Clin Nth Am 21: 471-502.

[3] Hardie JM ( 1982). The microbiology of dental caries. Dent Update 9 (4): 199-206.

[4] Jenkinson HF, Lamont RJ (2005). Oral microbial communities in sickness and in health. Trends Microbiology 13:89-95.

[5] Park KM., You JS., Lee HY., Baek NI., Hwang JK., Kuwanon G (2003). Antibacterial agent from the root bark of Morus alba against oral pathogens. J Ethnopharmacology 84: 181-185.

[6] Bidault P., Chandad F., Grenier D (2007). Risk of bacterial resistance associated with systemic antibiotic therapy in periodontology. J Can Dent Assoc 73: 721-725.

[7] Prabu GR., Gnanamani A., Sadulla S (2006). Guaijaverin - a plant flavonoid as potential antiplaque agent against Streptococcus mutans. J Appl Microbiology 101: 487-495.

[8] UNESCO (1996). Culture and Health, Orientation Texts - World Decade for Cultural Development 1988 1997, Document CLT/DEC/PRO - 1996, Paris, France, pgs. 129.

[9] Chitme HR., Chandra R., Kaushik S (2003). Studies on anti-diarrheal activity of Calotropis gigantea R. Br. in experimental animals. J Pharm Pharmaceut Science 7: 70-75.

[10] Gnanmani A, Shnmuga Priya K, Radhakrishann., Mary Baby (2003). Antibacterial activity of two plant extracts on eight burn pathogen J. ethonopharmacology 86: 59-61.

[11] Kim HS (2005). Do not put too much value on conventional medicines. J Ethnopharmacology 100: 37-39.

[12] Nimri LF., Meqdam MM., Alkofahi A (1999). Antibacterial activity of Jordanian medicinal plants. Pharmaceutical Biology 37 (3): 196-201.

[13] Silva O., Duarte A., Cabrita J., Gomes E (1996). Antimicrobial activity of Guinea - Bissau traditional remedies. Journal of Ethnopharmacology 50: 55-59.

[14] Cammue BPA, De Bolle MFC, Terras FRG, Proost P, Damme JV, Rees SB, Vanderleyden J and, Broekaert WF (1992). Isolationand characterization of a novel class of plant antimicrobial peptide from Mlrabilisjalapa L. seeds. J BiolChem 267:2228-2233.

[15]Linthorst HJM (1991). Pathogenesis related proteins of plants Critical Review. Plant Science 10:123-150.

[16] Liu (2000). Purification, characterization, and molecular cloning of the gene of a seed-specific antimicrobial protein from pokeweed. Plant Physiology 122:1015-1024.

[17] Jenssen H (2005). Anti-herpes simplex virus activity of lactoferrin/ lactoferricin an example of antiviral activity of antimicrobial protein/peptide. CellMol Life Science 62:3002-3013.

[18] Lehrer RI and Ganz T (1999). Antimicrobial peptides in mammalian and insect host defence. Curr Opinion Immunology 11:23-27.

[19] De Lucca AJ., Cleveland TE., Wedge DE (2005). Plant derived antifungal proteins and peptides. Can J Microbiology 51:1001-1014.

[20] Salahudin Muhammad Afzal1., Allah Bakhsh., Rauf Ahmad M., Irfan Manzoor., Sadia Liaquat ( 2011). Comparison of the antimicrobial activity of seed protein extracts from six medicinal plants against Staphylococcus aureus. Emir. J. Food Agricultutre 23 (1): 103-109.

[21] Kalpesh Ishnava and Pankit Shah (2014). Anticariogenic and hemolytic activity of selected seed protein extracts in vitro condition. Journal of Dentistry, Tehran University of Medical Sciences. 11(5):576-586.

[22] Chattopadhyay D., Maiti K., Kundu AP., Chakraborty MS., Bhadra R., Mandal SC., Manda AB (2001). Antimicrobial activity of Alstonia macrophylla - folklore of Bay Island. Journal of ethnopharmacology 77: 49-55.

[23] Thimmaiah SR (2006). Standard Methods Of Biochemical Analysis. Pp.96-97.

[24] Kareem S O., Akpan I., Ojo OP (2008). Antimicrobial activities of Calotropis procera on selected pathogenic microorganisms. African Journal of Biomedical Research11:105 - 110.

[25] Andra J., Jakovkin I., Grotzinger J., Hecht O., Krasnosdembskaya AD., Goldmann T., Gutsmann T., Leippe M (2008). Structure and mode of action of the antimicrobial peptide arenicin, Biochemistry Journal 410:113-122.

[26] Wang SY., Rao PF., Ye XY (2009). Isolation and biochemical characterization of a novel leguminous defense peptide with antifungal and antiproliferative potency. Appl. Microbiol. Biotechnology 82:79-86.

[27] Hiral Soni., Kalpesh Ishnava., Khushal Patel (2014). Anticariogenic activity and hemolytic study of some medicinal plants leaf extract against six oral pathogen in in vitro condition. International Journal of Applied Sciences and Biotechnology 2(3):253-259. 
[28] Solomon-Wisdom GO., Shittu GA (2010). In vitro antimicrobial and phytochemical activities of Acacia nilotica leaf extract. Journal of Medicinal Plants Research 4(12):1232-1234.

[29] Hud SH., Wanga JC., Kunga HF., Wanga JT., Leeb WL., Yangc YH (2004). Antimicrobial effect of extracts of cruciferous vegetables. Kaohsiung J. Med. Science 20:591-599.

[30] Pankit Shah (2011). Anticariogenic and hemolytic activity of selected seed protein extracts and their potential use in tooth infection. M.Sc. Dissertation thesis. Sardar Patel University, Anand, Gujarat, India.

[31] Jabeen R., Shahid M., Jamil A., Ashraf M (2008). Microscopic evaluation of the antimicrobial activity of seed extracts of Moringa oleifera. Pakistan J Botany 40:1349-1358.

[32] Kshipra Dhabhai andAmla Batra (2011). In vivo and in vitro protein profiling in Acacia nilotica (L.): A nitrogen fixing tree. African Journal of Microbiology Research 5(18):2793-2796.

[33] Emilson CG (1994). Potential efficacy of chlorhexidine against mutans streptococci and human dental caries. J Dent Research 73:682-691.

[34] Chalkley LJ and Koornholf HJ (1985). Antimicrobial activity of ciprofloxacin against Pseudomonas aeruginosa, Escharichia coli and Staphylococcus aureus determined by the kill curve method: Antibiotics comparison and synergistic interactions. Antimicrobial Agents and Chemotherapy 28:331- 342.

[35] Woolfrey BF and Enright M (1990). Ampicillin killing curve patterns for Ampicillin susceptible non typeable Haemophilus influenza strains by the agar dilution plate count method. Antimicrobial Agents and Chemotherapy 39: 1074-1087.

[36]Chung JY., Choo JH., Lee MH., Hwang JK (2006). Anticariogenic activity of macelignan isolated from Myristica fragrans (nutmeg) against Streptococcus mutans. Phytomedicine 13(4):261-266.

[37] Rehana A., Rabia S., Afzal M., Akthar S (2004). Inter and Intraspecific variation in SDS-AGE of total seed protein in rice (Oryza sativa L.) germplasm. Pak. J. Biol. Science 7: 139-143.

[38] Nakajima T., Naoki H., Corzo G., Dai L., Hisada M., Escoubas P., Yamaji N., Nagai H., Yasuda A., Andrianstiferana M., Haup J., Ohsiro N (2003). A trial of mass spectrometric characterization of femtomolar amount from subtropical islands. J Toxicol Toxin Rev 22:509-520.

Citation: Megha S Parekh, Kalpesh B Ishnava. "Antimicrobial and Hemolytic Activity of Seed Protein Extracts from Selected Medicinal Plants against Tooth Decaying Microorganisms". International Journal of Research Studies in Microbiology and Biotechnology (IJRSMB), vol. 6, no. 1, pp. 38-48, 2020. Available: DOI: http://dx.doi.org/ 10.20431/2454-9428.0601005

Copyright: (C) 2020 Authors. This is an open-access article distributed under the terms of the Creative Commons Attribution License, which permits unrestricted use, distribution, and reproduction in any medium, provided the original author and source are credited. 